\title{
CARACTERIZAÇÃO ANATÔMICA E CITOMÉTRICA EM BIRIBAZEIRO (Rollinia mucosa [Jacq.]) ${ }^{1}$
}

\author{
JOYCE DÓRIA RODRIGUES SOARES², GABRIELEN DE MARIA GOMES DIAS ${ }^{3}$, \\ FILIPE ALMENDAGNA RODRIGUES ${ }^{4}$, MOACIR PASQUAL ${ }^{5}$, EDVAN ALVES CHAGAS ${ }^{6}$
}

RESUMO - O biribazeiro (Rollinia mucosa [Jacq.]) é uma frutífera nativa da América Central e América do Sul que se destaca das demais espécies do gênero por apresentar frutos grandes e comestíveis. Tendo em vista que pouco se conhece a respeito da anatomia da planta, tipo de reserva da semente, como também sobre o conteúdo de DNA de espécies da família anonáceas, este trabalho teve por objetivos caracterizar histoquimicamente as sementes e anatomicamente as plântulas, e determinar o conteúdo de DNA de biribazeiro. As plântulas foram obtidas de sementes coletadas na região Amazônica pela Embrapa Roraima e enviadas à Universidade Federal de Lavras. Os frutos foram despolpados, e suas sementes foram previamente lavadas e semeadas em bandejas de 48 células, contendo como substrato pó de serragem, permanecendo em câmara de germinação a $30^{\circ} \mathrm{C}$ por 90 dias. Nas plantas obtidas, procedeu-se à análise histoquímica, à caracterização anatômica e à determinação do conteúdo de DNA. As principais conclusões deste trabalho foram que: (1) as sementes da Rollinia mucosa apresentam reserva principal lipídica; (2) as secções transversais da lâmina foliar indicam organização dorsiventral, do tipo hipoestomática com estômatos paracíticos e tricomas em ambas as faces da folha; (3) as folhas de biribazeiro apresentam, em média, 4,77 pg de DNA.

Termos para indexação: Anonaceae, anatomia, histoquímica, citometria fluxo.

\section{ANATOMICAL AND CYTOMETRIC CHARACTERIZATION IN BIRIBAZEIRO (Rollinia mucosa [Jacq.])}

\begin{abstract}
The biribazeiro (Rollinia mucosa [Jacq.]) is a native fruit of Central America and South America that stands out from the other species of the genus because it has large and edible fruits. Considering that little is known about the anatomy of the plant, the type of reserve of the seed, as well as little is known about the DNA content of species of Annonaceae family, this study aimed to characterize seeds histochemically and seedlings anatomically, and determine DNA content of biribazeiro (Rollinia mucosa [Jacq.]). The seedlings were obtained from seeds collected in the Amazon region by Embrapa Roraima and then, sent to UFLA, Federal University of Lavras, Minas Gerais State. The pulp of the fruits were extracted and the seeds were previously washed and sown in trays of 48 cells containing sawdust as substrate, remaining in a germination chamber at $30^{\circ} \mathrm{C}$ for 90 days. A histochemical analysis, anatomical characterization and determination of DNA content of the plants obtained were made. The main conclusions of this research were: (1) the seeds of Biribazeiro (Rollinia mucosa) present mainly lipid reserve, (2) The cross-sections of the leaf blade indicate dorsiventral organization, hypostomatic with paracitic stomata and trichomes on both sides of the sheet (3) the leaves of biribazeiro have on average $4.77 \mathrm{pg}$ of DNA.
\end{abstract}

Index terms: Anonaceae, anatomy, histochemistry, flow cytometry.

\footnotetext{
'(Trabalho 283-13) - Recebido em: 07-08-2013. Aceito para publicação em: 12-12-2013. V Congresso Internacional \& Encontro Brasileiro sobre Annonaceae: do gene à exportação (19 a 23 de Agosto).

${ }^{2}$ Pós-doutaranda Programa Nacional de Pós-Doutorado da Universidade Federal de Lavras (UFLA). E-mail: joycerodrigues01@ yahoo.com.br (autora para correspondência).

${ }^{3}$ Pós doutoranda Programa Nacional de Pós-Doutorado da Universidade Federal de Lavras (UFLA). E-mail: gabriellen@gmail.com ${ }^{4}$ Pós-doutorando Programa Nacional de Pós-Doutorado Institucional/UFLA. E-mail: filipealmendagna@yahoo.com.br ${ }^{5}$ Professor titular do Departamento de Agricultura/UFLA. E-mail: mpasqual@dag.ufla.br

${ }_{6}^{6}$ Pesquisador Embrapa Roraima. E-mail: edvan.chagas@cpafrr.embrapa.br
} 


\section{INTRODUÇÃO}

O biribazeiro (Rollinia mucosa [Jacq.], Annonaceae) é uma frutífera nativa da América Central e América do Sul. Por ser uma espécie tropical, desenvolve-se bem em áreas de clima quente e úmido, com temperaturas médias de 24 a $26^{\circ} \mathrm{C}$ e chuvas acima de $1.500 \mathrm{~mm}$ anuais (SANTOS et al., 2005). Destaca-se das demais espécies do seu gênero por apresentar frutos grandes e comestíveis, contendo polpa mucilaginosa e adocicada, o que justifica seu amplo cultivo nos neotrópicos.

O consumo das anonáceas no Brasil é crescente; e a oferta interna, insuficiente. A necessidade da disposição de maior número de dados e informações sobre o ciclo biológico das espécies, na tentativa de compreender os mecanismos naturais existentes no ecossistema florestal e a forma como as espécies renovam seus recursos e comportam-se em diferentes estádios de desenvolvimento, torna imprescindível a geração de conhecimentos básicos sobre compostos de reserva em sementes, a anatomia das plântulas e o conteúdo de DNA da espécie.

A identificação de plântulas conduz a três direções principais: (1) contribuição para melhor entendimento da biologia; (2) ampliação dos estudos taxonômicos e fundamentação de trabalhos de levantamentos ecológicos, nos aspectos de regeneração de áreas, em condições naturais, e (3) na ocupação e estabelecimento ambiental por qualquer espécie (SOBRINHO; SIQUEIRA, 2008). A preocupação pelos frequentes danos ocasionados ao meio ambiente reflete-se na conscientização de que é necessário conservar os ecossistemas ora existentes e, nessa ótica, os estudos anatômicos auxiliam no reconhecimento das espécies ainda em fase de plântula (CONTI et al., 2013) para possível regeneração natural de áreas degradadas. Os trabalhos mais recentes realizados com Rollinia mucosa [Jacq.] tratam de micropropagação (FIGUEIREDO et al., 2001), produção de mudas via estaquia (SCALOPPI JUNIOR; MARTINS, 2003), identificação de metabólitos secundários (KUO et al., 2001) e aclimatização (FERREIRA et al., 2010).

Tendo em vista a escassez de trabalhos a respeito desta espécie, objetivou-se caracterizar, histoquimicamente, as sementes, anatomicamente a plântula e determinar o conteúdo de DNA de biribazeiro (Rollinia mucosa [Jacq.]).

\section{MATERIAL E MÉTODOS}

Foram coletados frutos de biribazeiro na região Amazônica e enviados pela Embrapa Roraima para a Universidade Federal de Lavras, onde as sementes foram extraídas, lavadas e semeadas em bandejas de 48 células contendo como substrato pó de serragem. As sementes permaneceram em câmara de germinação a $30^{\circ} \mathrm{C}$ por 90 dias. Após este período, as plântulas (Figura 1) foram transferidas e conduzidas (em vasos) dentro de casa de vegetação coberta com plástico, com tela de sombreamento a $70 \%$ e sistema de nebulização intermitente. $\mathrm{O}$ experimento foi realizado entre os meses de setembro de 2011 e abril de 2012.

Análise histoquímica - Dez sementes foram conservadas em geladeira durante 10 dias e, em seguida, fixadas em álcool a $70 \%$. As regiões apical, mediana e basal do tecido de reserva destas sementes foram seccionadas à mão livre com auxílio de lâmina de barbear e, posteriormente, procedeu-se ao tratamento das secções com diferentes corantes específicos: Azul de Comassie para detecção de proteínas; Cloreto de Ferro III para detecção de compostos fenólicos; Lugol para detecção de amido, e Sudan IV para detecção de substâncias lipídicas (KRAUS; ARDUIN, 1997). As secções foram montadas em lâminas semipermanentes, e o material foi observado e fotografado em microscópio marca Olympus, modelo CX41, acoplado a uma câmera digital da marca Belcam, modelo DIV-3000.

Caracterização anatômica da plantaApós 210 dias do transplantio, cortes transversais foram realizados na folha mais nova (totalmente expandida) de diferentes plantas, no caule cortado na região próxima ao nó (Figura 1) e nas raízes cortadas nas pontas. As amostras foram fixadas em etanol a $70 \%$. Secções paradérmicas das faces abaxial e adaxial foram realizadas à mão livre, enquanto as secções transversais foram feitas em micrótomo de mesa. As secções foram colocadas em placas de Petri contendo hipoclorito de sódio a $1 \%$, durante 10 minutos. Em seguida, foram transferidas para água destilada por 10 minutos e coradas com Safranina a $1,0 \%$ e Safrablau (safranina a $1 \%$ e azul de Astra a 0,1\%) para secções paradérmicas e transversais, respectivamente. Posteriormente, foram montadas lâminas semipermanentes com glicerol a 50\% (KRAUS; ARDUIN, 1997). O material foi observado em microscópio Olympus CX41 acoplado a câmera digital Belcam DIV3000 e fotografado (15 campos). As medidas foram 
realizadas no software ImageTool 3.0, avaliandose: densidade estomática; relação diâmetro polar/ diâmetro equatorial dos estômatos; espessura da epiderme das faces abaxial e adaxial, e espessura de parênquimas esponjoso e paliçádico.

\section{Determinação do conteúdo de DNA -} Utilizaram-se três repetições de $300 \mathrm{mg}$ de folhas (Figura 1) e a mesma quantidade de massa foliar de ervilha (Pisum sativum) (padrão de referência de quantidade de DNA - 9,09 pg), que foram trituradas em placa de Petri, contendo $1 \mathrm{~mL}$ de tampão de extração de núcleos MARIE (DOLEZEL et al., 1989). Os histogramas foram obtidos no citômetro modelo FacsCalibur (Becton Dickinson) com o programa Cell Quest. As quantidades de DNA (pg) das plantas foram obtidas por meio da equação: quantidade de DNA (pg) = (posição do pico G1 da amostra $\div$ posição do pico G1 de ervilha ) x 9,09. A análise estatística dos dados foi realizada pelo programa WinMDI 2.8 .

\section{RESULTADOS E DISCUSSÃO}

\section{Análise histoquímica}

Os testes histoquímicos das secções tratadas com corantes evidenciaram a presença de lipídios nas sementes, devido à reação positiva ao teste com Sudan IV, em proporção maior do que proteínas, carboidratos e compostos fenólicos, o que pode ser indício de que a principal reserva energética das sementes do biribazeiro seja de origem lipídica (Figura 2). Estes resultados, apesar de qualitativos, corroboram aqueles obtidos por Kimbonguila et al. (2010) e Masruri et al. (2012), os quais verificaram que as sementes de Annona muricata e Annona squamosa, respectivamente, possuem maior teores de lipídios em detrimento das proteínas e dos carboidratos. As sementes têm sido estudadas quanto à composição química de suas reservas, e tal interesse não se dá apenas por seu teor nutritivo, mas por serem úteis na confecção de produtos industrializados (BUCKERIDGE et al., 2010).

As reservas da semente disponíveis para o crescimento da plântula não são determinadas somente pela sua massa, mas são também influenciadas pela sua composição química (CORTE et al., 2006). De acordo com o autor, a alta proporção de lipídios nas sementes de Caesalpinia peltophoroides pode ser uma característica adaptativa vantajosa à espécie, possibilitando o estabelecimento de plântulas em ambientes menos iluminados, devido ao maior conteúdo energético armazenado. Além disso, altos conteúdos de lipídios nas sementes de algumas espécies poderiam indicar uma seleção compensatória (maior energia/volume), à medida que as sementes mais leves são fortemente selecionadas, por exemplo, para melhor dispersão.

Como a reserva energética encontrada nas sementes do biribazeiro é de origem lipídica, o armazenamento da semente deve ser realizado com grau de umidade inferior ao da maioria das sementes amiláceas, pois as principais alterações em lipídios durante a deterioração são atribuídas às hidrólises enzimáticas, peroxidação e autoxidação. A temperatura necessária para a degradação do amido é mais elevada que a responsável pelos mesmos efeitos em oleaginosas. Nestas, uma elevação moderada da temperatura, como consequência do processo respiratório, é suficiente para a decomposição dos lipídios e a elevação da taxa de deterioração(GAGLIARDI; MARCOS FILHO, 2011).

Os testes histoquímicos são muito importantes para detecção de substâncias, uma vez que norteiam acerca das propriedades nutracêuticas e do potencial industrial de um fruto baseado em sua composição química (FANK-DE-CARVALHO; GRACIANORIBEIRO, 2005). Como a popularização de plantas nativas da Amazônia tem-se intensificado, é necessário maior empenho para que o conhecimento da flora dessa região seja satisfatório e de utilidade para a população. Outros tipos de testes histoquímicos, baseados no uso de corantes específicos, tais como os de detecção da presença de ácidos graxos, substâncias pécticas, sacarose, flavonoides e compostos fenólicos, são fundamentais para maior conhecimento dessas espécies amazônicas, muitas vezes pouquíssimo explorados, mas que podem ser utilizados para diversos fins. Apesar de a porção comestível do biribá ser a polpa, uma vez quantificadas tais substâncias nas sementes, estas podem ser utilizadas como agentes de defesa, antioxidantes, antibacterianos, que são algumas das utilizações de subprodutos do metabolismo secundário, como compostos fenólicos, que incluem fenóis e flavonoides, qualificados nos testes histoquímicos.

\section{Caracterização anatômica da planta}

As secções transversais da lâmina foliar do biribazeiro indicam organização dorsiventral das folhas, que são do tipo hipoestomática, com tricomas em ambas as faces (Figura 3). A epiderme é simples, com células de secção retangular a elíptica e paredes finas. Tricomas tectores simples, pluricelulares e unisseriados, com até 3 células, implantados em ambas as faces da lâmina, são mais abundantes 
sobre a nervura central na face abaxial. Estes tricomas possuem as funções de evitar a transpiração excessiva, de oferecer uma barreira contra ventos que podem diminuir a umidade relativa na superfície foliar e de proteger as folhas contra o excesso de água na superfície foliar (SILVA et al., 2005).

O mesofilo foliar é formado por parênquima paliçádico uniestratificado, constituído por células largas, com secções tendendo para o formato triangular, exibindo em geral extremos arredondados (Figura 4A). Essas células deixam entre si pequenos espaços intercelulares, que aparecem com mais frequência na região próxima ao parênquima esponjoso, o qual se apresenta com 3 a 4 estratos e células de secção lobada, que delimitam os espaços intercelulares que possuem dimensões variáveis, mas que geralmente são amplos. O tecido fundamental mostra-se homogêneo de forma geral, com reduzido número de feixes vasculares. A nervura central próxima à face abaxial apresenta células epidérmicas, em formato ligeiramente alongado no sentido periclinal, passando a secções de menor lúmen e paredes mais espessadas (Figura 4B). Na região proximal, a nervura destaca-se do mesofilo, apresentando maior número de camadas de parênquima na face abaxial e maior desenvolvimento do tecido vascular.

De acordo com os cortes paradérmicos (Figuras 4E e F), os estômatos encontram-se ao mesmo nível ou levemente projetados, com células estomáticas pequenas e paredes fortemente espessadas. As células epidérmicas revelam um contorno variável em consequência da sinuosidade das paredes celulares em ambas as faces, observando-se em torno da base dos tricomas uma disposição radiada. Os estômatos são observados apenas na face abaxial, sendo do tipo paracítico, distribuídos aleatoriamente, com densidade média de 104 estômatos por $\mathrm{mm}^{2}$. As células estomáticas possuem espessamento parietal nas regiões polares, podendo também verificar-se a presença de pequenas projeções, correspondentes a evaginações na parede das células anexas. Os estômatos são estruturas importantes para a produção vegetal, pois representam a porta de entrada e/ou de escoamento dos gases para a fotossíntese, processo primordial relacionado à produtividade vegetal. As diferentes espécies de plantas variam quanto ao número, frequência, tamanho, distribuição e forma dos estômatos, o que consequentemente interfere em sua capacidade fotossintética. Mesmo em uma única planta, as folhas variam quanto aos estômatos, dependendo de sua forma e da posição das folhas na copa (SILVA et al., 2005).

O caule do biribazeiro ( $R$. mucosa) possui epiderme unisseriada, recoberta pela cutícula, porém sem a presença de tricomas (Figura 4C). Abaixo da epiderme, encontra-se o córtex, com cinco a seis camadas de células do colênquima e parênquima cortical com células achatadas, com apenas duas a três camadas, demonstrando um caule em crescimento primário. A medula da raiz é formada de parênquima medular com grandes células de formato isodiamétrico e sistema vascular composto por feixes colaterais abertos, delimitando um caule eustélico típico com os feixes vasculares arranjados de forma circular no entorno da medula. $\mathrm{O}$ sistema vascular na região amostrada encontra-se em desenvolvimento primário. Os estudos da anatomia de caule e raiz revelam diferenças e similaridades estruturais entre os dois órgãos e ajudam a entender melhor as adaptações das plantas a diferentes condições ambientais (GOULART; MARCATI, 2008); porém, como no caso do biribá, nem todas as plantas apresentam essa tendência.

No corte transversal da raiz de biribazeiro, observou-se epiderme uniestratificada, a exoderme situa-se abaixo da epiderme contendo uma camada de células. Possivelmente, essa camada de células pode funcionar como uma barreira apoplástica ao fluxo de água e íons (HARTUNG et al., 2002), as chamadas estrias de Caspary. A camada interna do córtex diferenciou-se em uma endoderme, que de acordo com Dalla et al. (1999) é uma barreira apoplástica formada pelo espessamento de paredes primárias de células da porção mais interna do córtex de raízes primárias, formando um anel de células no entorno do sistema vascular; além disso, atua como proteção ao periciclo e aos tecidos condutores de prováveis danos ocasionados por fatores ambientais adversos como a presença de metais pesados ou salinidade. Por outro lado, esse espessamento pode dificultar o fluxo de água para o cilindro vascular, o que contribuiria para a perda da condutividade hidráulica da raiz (PEREIRA et al., 2008). Neste sentido, cabe salientar que a organização interna das raízes é bastante variada de um modo geral, porém é mais simples e filogeneticamente mais primitiva do que a do caule. Quando examinada em corte transversal, a raiz primária mostrou uma nítida separação entre os três sistemas de tecidos: epiderme (sistema dérmico), córtex (sistema fundamental) e tecidos vasculares (sistema vascular).

\section{Determinação do conteúdo de DNA}

A quantidade de DNA nuclear de um dado organismo, normalmente referida como valor $\mathrm{C}$, referindo-se a letra $\mathrm{C}$ ao termo constante, expressa o tamanho do genoma, ou seja, a quantidade de 
material genético existente (BENNET; LEITCH, 2000). A análise das folhas de biribazeiro mostrou que a espécie possui, em média, 4,77 pg de DNA por grama de massa fresca, sendo o coeficiente de variação da análise em torno de 0,56 (Tabela 1 e Figura 4). A quantidade de DNA nuclear tem significado adaptativo e influencia o fenótipo de duas maneiras distintas, ou seja, pela expressão de seu conteúdo e pelos seus efeitos físicos (SCHIFINO-WITTMANN, 2001).

O valor C de DNAé um caráter de significado biológico fundamental, e o conhecimento da quantidade de DNA nuclear de um grupo de organismos pode ser útil em vários campos, como biologia molecular e celular, ecologia, fitogeografia e sistemática (BENNET; LEITCH, 2000). Como a espécie $R$. mucosa, apesar do seu grande potencial para consumo, industrialização e fitoquímico, ainda está incipiente tanto a nível anatômico quanto molecular, a caracterização destes tópicos, por isso, faz-se necessária, a caracterização de todo banco de germoplasma da espécie após sua formação, e uma vez identificada a determinação do conteúdo de DNA permitirá o agrupamento das espécies em grupos distintos.

Do ponto de vista prático, a determinação da quantidade de DNA nuclear pode substituir a contagem de cromossomos, especialmente quando se trabalha com um número muito grande de indivíduos, como, por exemplo, em bancos de germoplasma. $O$ conhecimento do número de cromossomos, ou do nível de ploidia, além de ser importantíssimo para a caracterização do germoplasma, é imprescindível para os trabalhos de melhoramento genético, quando são programados cruzamentos. A determinação do número de cromossomos, apesar de ser uma técnica relativamente simples, demanda tempo. Sua substituição por uma técnica mais expedita, que dê um resultado semelhante, ou seja, indique o nível de ploidia com um grau aceitável de precisão permite agilizar uma série de trabalhos, seja de manutenção de germoplasma, seja de seleção, seja nas progênies de cruzamentos de indivíduos com os níveis de ploidia desejados.
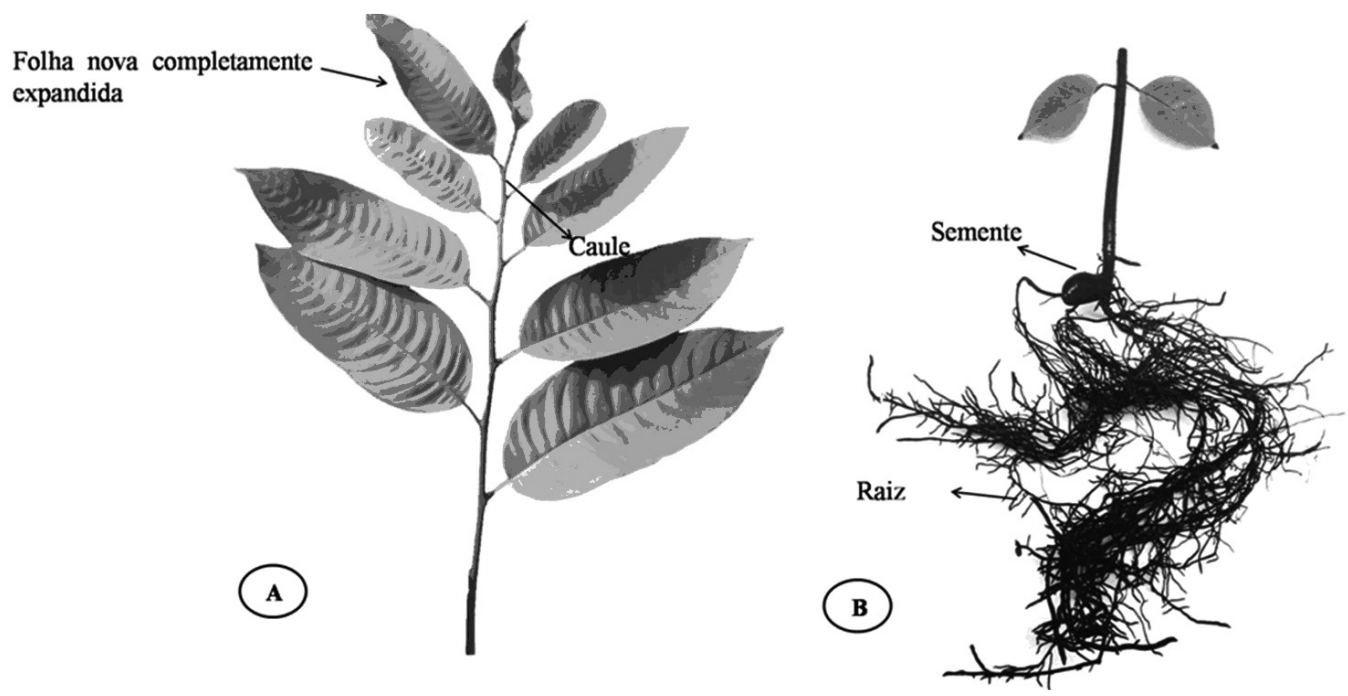

FIGURA 1 - (A) Parte aérea; (B) Sistema radicular de biribazeiro identificando as partes principais analisadas no estudo. 

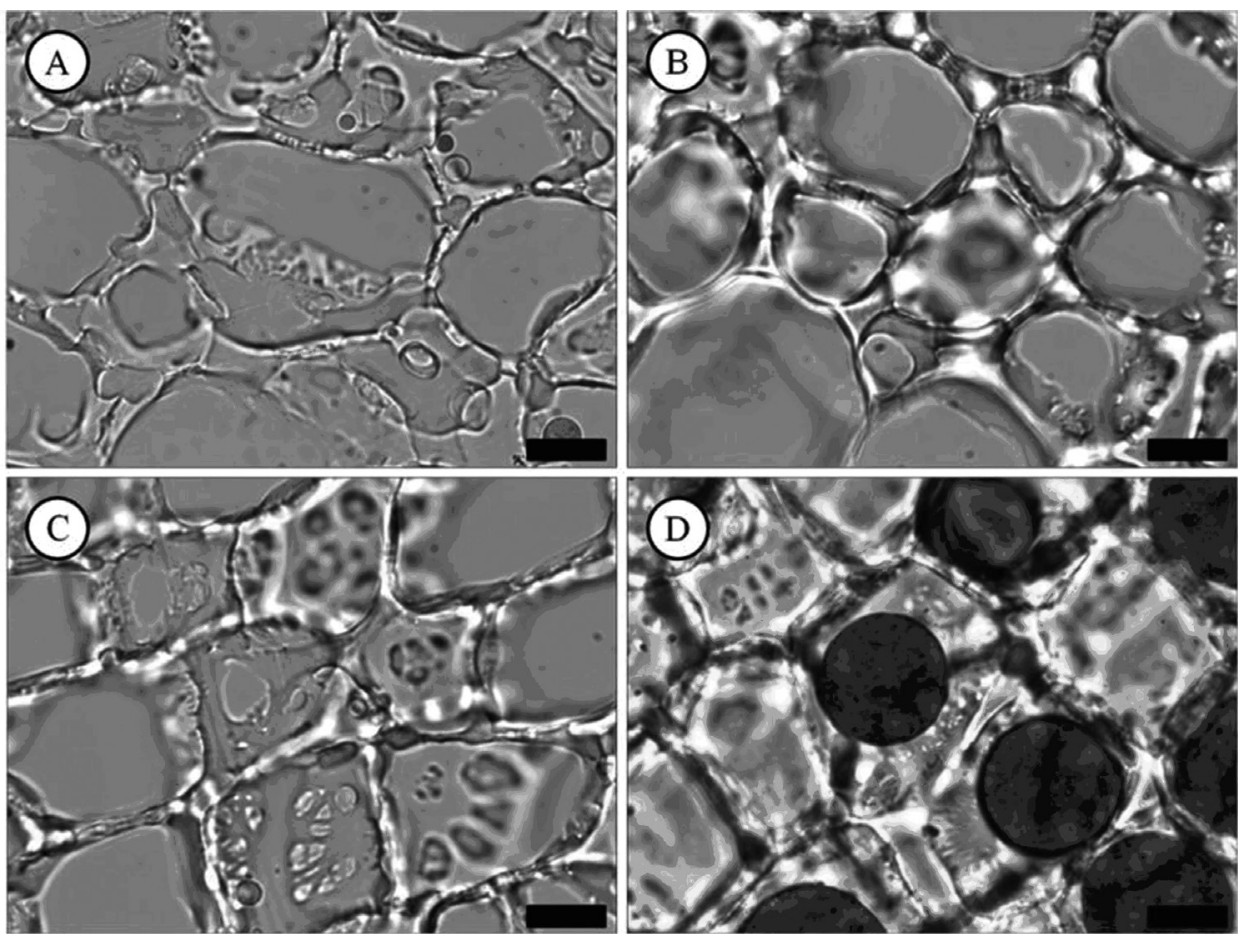

FIGURA 2 - Representação dos testes histoquímicos de secções trasnversais do tecido de reserva em sementes de biribazeiro (Annona mисоsa) em diferentes corantes específicos. A) Cloreto de ferro III (negativo); B) azul de cornassie (negativo); C) lugol (negativo); D) sudan IV (positivo). Barra $=200 \mathrm{~m}$. UFLA, Lavras,2011.

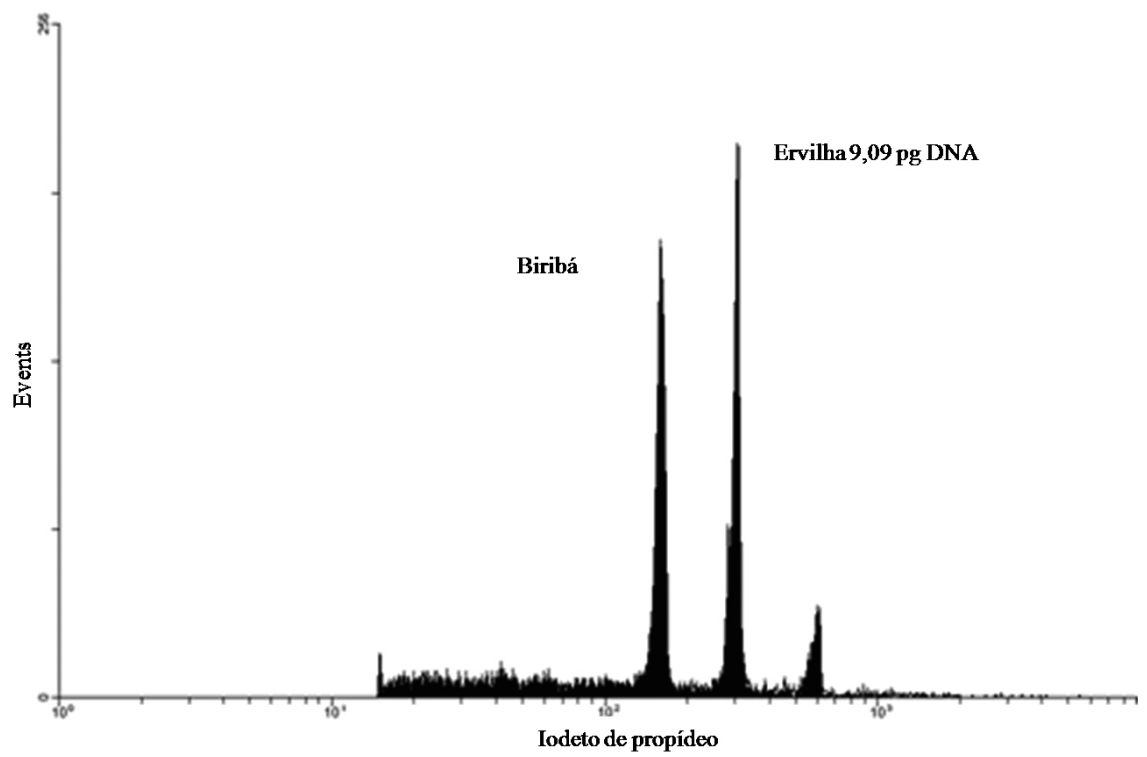

FIGURA 3 - Historama de citometria de fluxo obtido com o tampão de extração núcleos Marie. O primeiro pico representa o pico G1 da amostra de biribazeiro ( Rollinia mucosa) e o segundo é o pico G1 da ervilha (Pisum sativum L.). UFLA, Lavras, 2013. 
(A)

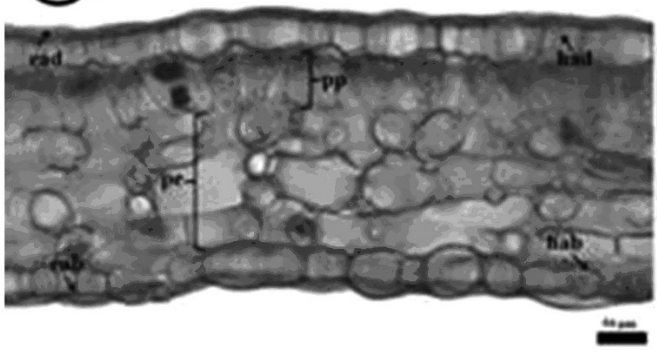

(C)
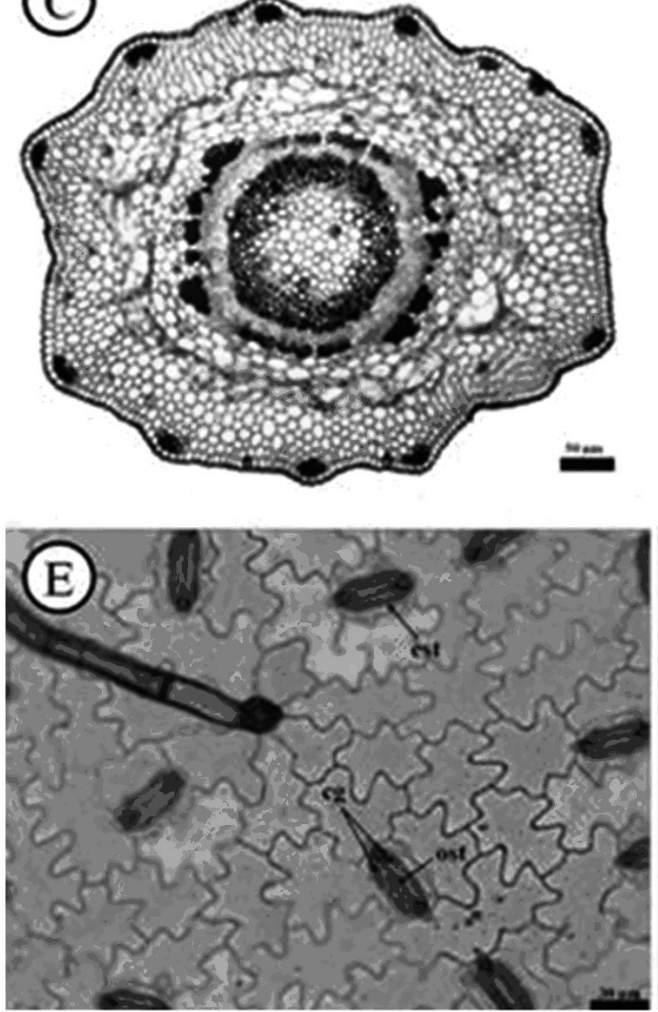

(B)

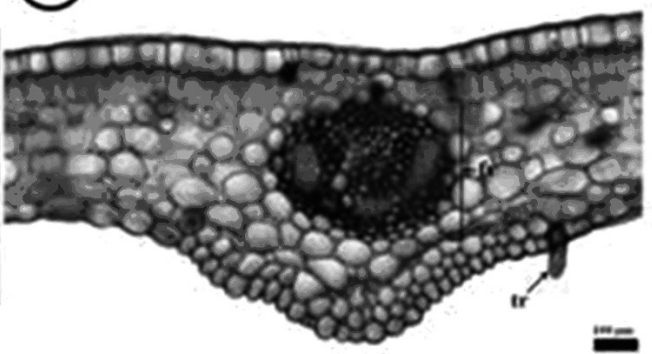

(D)
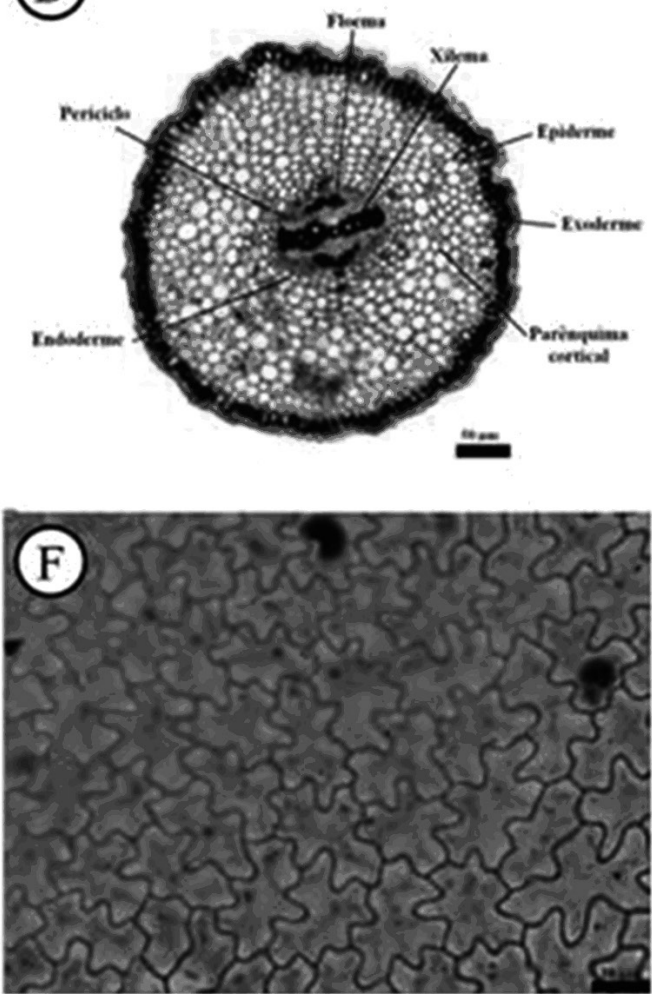

FIGURA 4 - Secções transversais da lâmina foliar de Biribazeiro (Rollinia mucosa). A) lâmina foliar - mesofilo; B) lâmina foliar - nervura central; C) caule; D) raiz; Secções paradérmicas. E) face abaxial e F) face adaxial. Legendas: $\mathrm{tr}=$ tricoma; ead= epiderme da face adaxial; $p p=$ parênquima paliçádico; $p e=$ parênquima esponjoso; $e a b=$ epiderme da face abaxial; had= hipod; $\mathrm{fv}=$ feixe vascular; est $=$ estômato; ost $=$ ostíolo; $\mathrm{cg}=$ células-guardas. UFLA, Lavras, 2013. 


\section{CONCLUSÃO}

1-A semente de biribazeiro (Rollinia mucosa) apresenta principal reserva lipídica.

2-As secções transversais da lâmina foliar indicam organização dorsiventral, do tipo hipoestomática, com estômatos paracíticos e tricomas em ambas as faces da folha.

3-+++As folhas de biribazeiro apresentam, em média, 4,77 pg de DNA.

\section{REFERÊNCIAS}

BENNET, M.D.; LEITCH, I.J. Nuclear DNA amounts in angiosperms and their modern uses - 807 new estimates. Annals of Botany, London, v.86, p.859-909, 2000.

BUCKERIDGE, M. S. Seed Cell Wall Storage Polysaccharides: models to understand cell wall biosynthesis and degradation. Plant Physiology, Minneapolis, v. 154, p. 1-7, 2010.

CONTI, D.; RIBEIRO, M.F.; RASEIRA, M.C.B.; PETERS, J.A.; BIANCHI, V.J. Caracterização anatômico-fisiológica da compatibilidade reprodutiva de ameixeira-japonesa. Revista Brasileira de Fruticultura, Jaboticabal, v.35, n.3, p. 695-703, 2013.

CORTE, V.B.; BORGES, E.E.L.; PONTES, C.A.; LEITE, I.T.A.; VENTRELLA, M.C.; MATHIAS, A.A. Mobilização de reservas durante a germinação das sementes e crescimento das plântulas de caesalpinia peltophoroides benth. (Leguminosaecaesalpinoideae). Revista Árvore, Viçosa, MG, v.30, n.6, p.941-949, 2006.

DALLAVECHIA, F.; CUCCATO, F.; LAROCCA, N.; LARCHER, W.; RASCIO, N. Endodermis-like sheaths in the submerged freshwater macrophyte Ranunculus trichophyllus Chaix. Annals of Botany, London, v.83, p.93-97, 1999.

DOLEZEL, J.; BINAROVA, P.; LUCRETTI, S. Analysis of nuclear DNA content in plant cells by flow cytometry. Biologia Plantarum, Praha, v.31, n.2, p.113-120, 1989.
FANK-DE-CARVALHO, S.M.; GRACIANORIBEIRO, D. Arquitetura, anatomia e histoquímica das folhas de Gomphrena arborescens L.f. (Amaranthaceae). Acta Botanica Brasílica, Porto Alegre, v.19, n.2, p.377-390, 2005.

FERREIRA, M.G.R.; S, M.R.A.; S, E.O.; G, E.P., A, E.U., B, R.L.A. Emergência e crescimento inicial de plântulas de biribá (Rollinia mucosa (Jacq.) Baill) (Annonaceae) em diferentes substratos. Semina: Ciência Agrárias, Londrina, v.31, n.2, p.373-380, 2010.

FIGUEIREDO, S.F.L.; ALBARELLO, N.; VIANA, V.R.C. Micropropagation of Rollinia mucosa (JACQ.) baill. In Vitro Cellular \& Developmental Biology Plant, Heidelberg, v.37, n.4, p.471-475, 2001.

GAGLIARDI, B.; MARCOS-FILHO, J. Relationship between germination and bell pepper seed structure assessed by the X-ray test. Scientia Agrícola, Piracicaba, v. 68, p. 411-416, 2011.

GOULART, S.L.; MARCATI, C.R. Anatomia comparada do lenho em raiz e caule de Lippia salviifolia Cham. (Verbenaceae). Revista Brasileira de Botânica, São Paulo, v.31, n.2, p.263-275, 2008.

HARTUNG, W.; SAUTER, A.; HOSE, E. Abscisic acid in the xylem: where does it come from, where does it go to? Journal of Experimental Botany, Oxford, v. 53, n. 366, p. 27-32, 2002.

KIMBONGUILA, A.; NZIKOU, J.M.; MATOS, L.; LOUMOUAMOU, B.; NDANGUI, C.B.Proximate Composition and Physicochemical Properties on the Seeds and Oil of Annona muricata grown In CongoBrazzaville. Research Journal of Environmental and Earth Sciences, Orissa, v.2, n.1, p.13-18, 2010.

KRAUS, J. E.; ARDUIM, M. Manual básico de métodos em morfologia vegetal. Seropédica: EDUR, 1997. 198 p.

KUO, R.Y.; CHANG, F.R.; CHEN C.Y.; TENG, C.M.; YEN, H.F.; WU, Y.C. Antiplatelet activity of N-methoxycarbonyl aporphines from Rollinia mucosa. Phytochemistry, New York, v.57, n.3, p.421-425, 2001. 
MASRURI, L.; MUKESH, S.; WARSITO, L.; PRASETYO, A. Renewable Oil Extracted from Indonesian Srikaya's (Annona squamosa sp.). Seed: Another Potent Source for Biodiesel. Journal Pure Applied Chemistry Research, Turabo, v.1, n.1, p.51-57, 2012.

PEREIRA, F.J.; CASTRO, E.M.; SOUZA, T.C.; MAGALHÃES, P.C. Evolução da anatomia radicular do milho-'Saracura'. Pesquisa Agropecuária Brasileira, Brasília, v.43, n.12, p.1.649-1.656, 2008.

SANTOS, C.E.; ROBERTO, S.R.; MARTINS, A.B.G. Propagação do biribá (Rollinia mucosa) e sua utilização como porta-enxerto de pinha (Annona squamosa). Acta Scientarum, Maringá, v. 27, n. 3, p. 433-436, 2005.

SCALOPPI JÚNIOR, E.J.; MARTINS, A.B.G. Clonagem de quatro espécies de annonaceae potenciais como porta-enxertos. Revista Brasileira de Fruticultura, Jaboticabal, v.25, n.2, p.286-289, 2003.
SCHIFINO-WITTMANN, M.T. Determinação da quantidade de DNA nuclear em plantas. Ciência Rural, Santa Maria, v.31, n.5, p.897-902, 2001.

SILVA, L.M.; ALQUINI, Y.; CAVALLET, V.J. Inter-relações entre a anatomia vegetal e a produção vegetal. Acta Botanica Brasilica, Porto Alegre, v.19, n.1, p.183-194, 2005.

SOBRINHO, S.P.; SIQUEIRA, A.G. Caracterização morfológica de frutos, sementes, plântulas e plantas jovens de mutamba (Guazuma ulmifolia Lam. Sterculiaceae). Revista Brasileira de Sementes, Londrina, v.30, n.1, p.114-120, 2008. 